\title{
DETERMINAN TERHADAP PENYEMBUHAN LUKA PERINEUM PADA IBU NIFAS DI PRAKTIK MANDIRI BIDAN KOTA PALANGKARAYA
}

\section{Determinants Of Perineum Wound Healing on Post Partum Mother at Independent Practice Of Midwives Palangka Raya City}

\author{
Yuniarti ${ }^{\text {I* }}$ \\ Cahaya Asi ${ }^{2}$ \\ Dea Aprilia ${ }^{3}$ \\ Sherly Veronika ${ }^{4}$ \\ ${ }^{*} 1,2,3,4$ Jurusan Kebidanan, \\ Poltekkes Kemenkes Palangka \\ Raya, Kalimantan Tengah, \\ Indonesia. \\ *email: yuniartiamit@gmail.com
}

\begin{abstract}
Abstrak
Latar Belakang : Kematian maternal di Indonesia terkait persalinan adalah infeksi I I\% berawal dari penatalaksanaan ruptur perineum yang kurang baik. Sekitar $85 \%$ wanita melahirkan pervaginam mengalami trauma perineum dan kurang dari $1 \%$ episiotomi atau ruptur perineum mengalami infeksi.

Tujuan :Tujuan umum penelitian ini untuk menganalisis faktor-faktor yang berhubungan dengan penyembuhan luka perineum pada ibu nifas.

Metode : Jenis penelitian ini adalah analitik observasional dengan rancangan cross sectional. Teknik sampling yang digunakan adalah purposive sampling. Sampel penelitian ini adalah 60 ibu nifas hari ke-7 yang mengalami ruptur perineum derajat Il di PMB wilayah Kota Palangka Raya.

Hasil : Hasil analisis Uji Chi-Square bahwa terdapat hubungan signifikan antara Pendidikan ( $p$-value $=0,010$ ), status gizi $(p$-value $=0,00 \mathrm{I})$ dan kadar hemoglobin $(0,000)$ dengan penyembuhan luka perineum.

Kesimpulan : Ada hubungan antara Pendidikan, status gizi dan kadar hemboglobin terhadap penyembuhan luka perineum.
\end{abstract}

\section{Abstract}

Background : Maternal mortality in Indonesia related to childbirth is $11 \%$ infection starting from poor management of perineal rupture. Approximately $85 \%$ of women who deliver vaginally have perineal trauma and less than $1 \%$ of episiotomy or perineal ruptures have infection.

Objective : The general objective of this study was to analyze the factors that influence the healing of perineal wounds in postpartum women.

Methods: This research is an analytic observational with a cross sectional design. The sampling technique used is purposive sampling. The sample of this study was postpartum women who experienced a second degree perineal rupture in PMB in the Palangka Raya City.

Results: The results of the Chi-Square test analysis showed a significant relationship between education ( $p$-value $=0.010)$, nutritional status $(p$-value $=$ $0.00 \mathrm{I}$ ) and hemoglobin levels $(0.000)$ with the duration of perineal wound healing.

Conclusion : There is a relationship between education, nutritional status and hemoglobin levels on perineal wound healing.

(c) yearThe Authors. Published by Institute for Research and Community Services Universitas Muhammadiyah Palangkaraya. This is Open Access article under the CC-BY-SA License (http://creativecommons.org/licenses/by-sa/4.0/). DOI: https://doi.org//0.33084/jsm.vxix.xxx.

\section{PENDAHULUAN}

Luka perineum bisa terjadi pada semua persalinan, biasanya robekan terjadi di garis tengah dan dapat meluas apabila kepala janin lahir terlalu cepat. Pelaksanaan perawatan luka yang kurang baik dapat menyebabkan ibu mengalami berbagai masalah, bahkan dapat berlanjut menjadi infeksi. Jika di tinjau dari penyebab kematian ibu, infeksi merupakan penyebab kematian terbanyak nomor dua setelah perdarahan sehingga sangat tepat jika para tenaga kesehatan memberikan perhatian tinggi pada masa ini(Rohmin et al., 2017).

Di Provinsi Kalimantan Tengah penyebab kematian lbu di dominasi oleh perdarahan (34\%), hipertensi dalam kehamilan (24\%), diikuti infeksi 3\%, gangguan sistem peredaran darah $3 \%$ dan penyebab lain (non obstetric) sebesar 20\%. (Dinas Kesehatan Provinsi Kalimantan Tengah, 2019)

Dalam penelitian Yuniarti tahun 2018, Kenneth J. Leveno (2009) mengatakan bahwa kematian maternal di Indonesia terkait persalinan adalah infeksi II\% 
berawal dari penatalaksanaan ruptur perineum yang kurang baik. Sekitar $85 \%$ wanita yang melahirkan spontan pervaginam mengalami trauma perineum dan kurang dari $1 \%$ episiotomi atau ruptur perineum mengalami infeksi (Yuniarti, 2018).

Faktor terpenting yang memudahkan terjadi infeksi pada masa nifas adalah perdarahan dan trauma persalinan karena perdarahan dapat menurunkan daya tahan tubuh ibu. Trauma persalinan menjadi pintu masuk bagi mikroorganisme, selain itu jaringan neukrotis merupakan media yang subur bagi mikroorganisme untuk berkembang. Keadaan umum ibu mrupakan faktor yang turut menentukan terjadinya infeksi seperti kurangnya kadar hemoglobin dan kurangnya status gizi karena dapat melemahkan tubuh ibu sehingga terjadi keterlambatan dalam penyembuhan luka perineum (Pujiastuti \& Hapsari, 20I7).

Dalam penelitian Rohmin tahun 2017, tingkat pendidikan merupakan salah satu faktor yang mempengaruhi penyembuhan luka perineum. Menurut Notoadmojo (2014) menyatakan bahwa pendidikan seseorang sangat menentukan dalam pengambilan keputusan dan penerimaan informasi. Hal ini berarti bahwa tingkat pendidikan seseorang yang rendah kemungkinan akan sulit menerima masukan tentang cara perawatan luka perineum. Informasi tentang perawatan perineum juga telah didapat seseorang yang mempunyai paritas lebih pada masa nifas sebelumnya.(Rohmin et al., 2017)

Berdasarkan latar belakang tersebut, maka penulis tertarik untuk melakukan penelitian mengenai "faktor pendidikan, status gizi, dan kadar hemoglobin terhadap penyembuhan luka perineum pada ibu nifas"

\section{METODOLOGI}

Penelitian ini menggunakan jenis penelitian analitik observasional dengan desain cross sectional. Tujuan dari penelitian ini adalah untuk menganalisis faktor-faktor terhadap penyembuhan luka perineum ibu nifas di PMB wilayah Kota Palangka Raya. Menggunakan rumus
Lemeshow diperoleh jumlah Sampel dalam penelitian ini 60 ibu nifas hari ke-7 dengan luka perineum derajat II yang di ambil dari 8 PMB di wilayah Kota Palangka Raya. Teknik pengumpulan data dilakukan dengan menggunakan lembar observasi untuk wawancara, pengukuran berat badan dan tinggi badan, pengukuran kadar hemoglobin menggunakan Haemometer dan format skala REEDA untuk menilai penyembuhan luka perineum. Analisa data yang digunakan adalah uji ChiSquare.

\section{HASIL}

Tabel I. Distribusi Frekuensi Penyembuhan Luka Perineum Ibu Nifas Hari Ke- 7

\begin{tabular}{ccc}
\hline Penyembuhan Luka Perineum & n & $\%$ \\
\hline Sembuh & 33 & 55 \\
& & \\
\hline Tidak Sembuh & 27 & 45 \\
\hline Jumlah & 60 & 100
\end{tabular}

Berdasarkan tabel I diketahui distribusi frekuensi dari 60 responden responden menurut penyembuhan luka perineum yang sembuh sebanyak 33 (55\%) responden, sedangkan yang tidak sembuh hari sebanyak 27 (45\%) responden.

Tabel 2. Hubungan Pendidikan dengan Penyembuhan Luka Perineum Ibu Nifas Hari Ke- 7

\begin{tabular}{|c|c|c|c|c|c|c|c|}
\hline \multirow{3}{*}{ Pendidikan } & \multicolumn{4}{|c|}{$\begin{array}{c}\text { Penyembuhan Luka } \\
\text { Perineum }\end{array}$} & \multirow{2}{*}{\multicolumn{2}{|c|}{ Jumlah }} & \multirow[t]{3}{*}{$\begin{array}{c}\rho \\
\text { value }\end{array}$} \\
\hline & \multicolumn{2}{|c|}{ Sembuh } & \multicolumn{2}{|c|}{$\begin{array}{c}\text { Tidak } \\
\text { Sembuh }\end{array}$} & & & \\
\hline & $\mathrm{n}$ & $\%$ & $\mathrm{n}$ & $\%$ & $\mathrm{n}$ & $\%$ & \\
\hline Tinggi & 25 & $4 I, 7$ & 8 & 13,3 & 33 & 55 & 0,01 \\
\hline Rendah & 12 & 20 & 15 & 25 & 27 & 45 & \\
\hline Jumlah & 37 & 61,7 & 23 & 38,3 & 60 & 100 & \\
\hline
\end{tabular}

Berdasarkan tabel 2 menunjukkan bahwa Berdasarkan tabel diatas menunjukkan bahwa dari 33 (55\%) responden dengan pendidikan tinggi, yang luka perineumnya sembuh sebanyak $25(41,7 \%)$ responden dan yang luka perineumnya tidak sembuh sebanyak 8 (13,3\%) responden. Sedangkan dari 27 (45\%) responden yang memiliki pendidikan rendah, yang luka perineumnya sembuh sebanyak 12 (20\%) responden 
dan yang luka perineumnya tidak sembuh sebanyak I5 (25\%) responden.

Hasil analisis uji chi square diperoleh $\rho$ value lebih kecil dari nilai $\alpha(0,01<0,05)$ yang berarti terdapat hubungan antara tingkat pendidikan dengan penyembuhan luka perineum.

Tabel 3. Hubungan Status Gizi dengan Penyembuhan Luka Perineum

\begin{tabular}{|c|c|c|c|c|c|c|c|}
\hline \multirow{3}{*}{$\begin{array}{l}\text { Status } \\
\text { Gizi }\end{array}$} & \multicolumn{4}{|c|}{$\begin{array}{c}\text { Penyembuhan Luka } \\
\text { Perineum }\end{array}$} & \multicolumn{2}{|c|}{ Jumlah } & \multirow[t]{3}{*}{$\begin{array}{c}\rho \\
\text { value }\end{array}$} \\
\hline & \multicolumn{2}{|c|}{ Sembuh } & \multicolumn{2}{|c|}{$\begin{array}{c}\text { Tidak } \\
\text { Sembuh }\end{array}$} & & & \\
\hline & $\mathrm{n}$ & $\%$ & $\mathrm{n}$ & $\%$ & $\mathrm{n}$ & $\%$ & \\
\hline Normal & 30 & 50 & 7 & 11,6 & 37 & 61,4 & 0,001 \\
\hline $\begin{array}{l}\text { Tidak } \\
\text { Normal }\end{array}$ & 4 & 6,7 & 19 & 31,7 & 23 & 38,4 & \\
\hline Jumlah & 18 & 56,7 & 12 & 43,3 & 60 & 100 & \\
\hline
\end{tabular}

Berdasarkan tabel 3 menunjukkan bahwa dari 37 $(6 \mathrm{I}, 4 \%)$ responden yang memiliki status gizi normal, yang luka perineumnya sembuh sebanyak 30 (50\%) responden dan yang luka perineumnya tidak sembuh sebanyak 7 (1I,6\%) responden. Sedangkan dari 23 $(38,4 \%)$ respoden yang memiliki status gizi tidak normal, yang luka perineumnya sembuh sebanyak 4 $(6,7 \%)$ responden dan yang luka perineumnya tidak sembuh sebanyak 12 (43,3\%) responden.

Hasil analisis uji chi square diperoleh $\rho$ value 0,00 I lebih kecil dari nilai $\alpha(0,05)$ yang berarti terdapat hubungan antara status gizi dengan penyembuhan luka perineum.

Tabel 4. Hubungan Kadar Hemoglobin dengan Penyembuhan Luka Perineum

\begin{tabular}{|c|c|c|c|c|c|c|c|}
\hline \multirow{3}{*}{$\begin{array}{l}\text { Kadar } \\
\text { Hb }\end{array}$} & \multicolumn{4}{|c|}{$\begin{array}{c}\text { Penyembuhan Luka } \\
\text { Perineum }\end{array}$} & \multicolumn{2}{|c|}{ Jumlah } & \multirow[t]{3}{*}{$\begin{array}{c}\rho \\
\text { value }\end{array}$} \\
\hline & \multicolumn{2}{|c|}{ Sembuh } & \multicolumn{2}{|c|}{$\begin{array}{c}\text { Tidak } \\
\text { Sembuh }\end{array}$} & & & \\
\hline & $\mathrm{n}$ & $\%$ & $\mathrm{n}$ & $\%$ & $\mathrm{n}$ & $\%$ & \\
\hline Normal & 29 & 48,3 & 4 & 6,7 & 33 & 55 & 0,000 \\
\hline $\begin{array}{l}\text { Tidak } \\
\text { Normal }\end{array}$ & 12 & 20 & 15 & 25 & 27 & 45 & \\
\hline Jumlah & 4 I & 68,3 & 19 & 31,7 & 60 & 100 & \\
\hline
\end{tabular}

Berdasarkan tabel 4 menunjukkan bahwa dari 33 (55\%) responden yang memiliki kadar hemoglobin normal, yang luka perineumnya sembuh sebanyak 29 (48,3\%) responden dan yang luka perineumnya tidak sembuh sebanyak 4 (6,7\%) responden. Sedangkan dari 27 (45\%) respoden yang memiliki kadar hemoglobin tidak normal, yang luka perineumnya sembuh sebanyak 12 (20\%) responden dan yang luka perineumnya tidak sembuh sebanyak $19(31,7 \%)$ responden.

Hasil analisis uji chi square diperoleh $\rho$ value 0,000 lebih kecil dari nilai $\alpha(0,05)$ yang berarti terdapat hubungan antara kadar hemoglobin dengan penyembuhan luka perineum.

\section{PEMBAHASAN}

\section{Hubungan Pendidikan dengan Penyembuhan Luka Perineum}

Hasil analisis uji chi square diperoleh $\rho$ value 0,0 llebih kecil dari nilai $\alpha(0,05)$ yang berarti $\mathrm{Ha}$ diterima dan Ho ditolak yaitu terdapat hubungan antara tingkat pendidikan dengan penyembuhan luka perineum.

$\mathrm{Hal}$ ini sejalan dengan hasil penelitian Utami yang berjudul "Hubungan Perawatan Perineum dengan Kesembuhan Luka Perineum pada Ibu Nifas di Klinik Bersalin Widuri Sleman”, bahwa pada dasarnya tingkat pendidikan berpengaruh terhadap penyembuhan luka perineum. Ibu nifas dengan pendidikan yang baik akan memiliki pengetahuan yang lebih besar jika dibandingkan dengan ibu nifas yang berpendidikan rendah (Utami, 20I7). Tingkat pendidikan mempunyai hubungan yang eksponensial dengan tingkat kesehatan, Semakin tinggi tingkat pendidikan maka semakin mudah menerima informasi yang di terima. Konsep hidup sehat secara mandiri, kreatif dan berkesinambungan. Latar belakang pendidikan seorang ibu sangat berpengaruh terhadap tingkat pengetahuan ibu (Notoatmodjo, 2014). Teori ini sesuai dengan penelitian Intiyaswati (2017), bahwa pendidikan sangat mempengaruhi penyembuhan luka karena semakin tinggi tingkat pendidikan seseorang maka semakin mudah menerima informasi dan dapat mengambil keputusan yang baik dan benar untuk kesembuhan luka perineum (Intiyaswati, 2017). Sri Susilawati juga mengatakan dalam penelitiannya yang berjudul “Determinan Lama Penyembuhan Luka Perineum pada 
Ibu Nifas" bahwa terdapat hubungan yang signifikan antara pendidikan ibu dengan lama penyembuhan luka perineum pada ibu postpartum (Susilawati et al., 2020).

Hubungan Status Gizi dengan Penyembuhan Luka Perineum

Berdasarkan hasil analisis uji chi square diperoleh $\rho$ value 0,00 I lebih kecil dari nilai $\alpha(0,05)$ yang berarti terdapat hubungan antara status gizi dengan penyembuhan luka perineum. Hasil penelitian ini di dukung oleh hasil penelitian Yuniarti, 2020 bahwa Hasil analisa menggunakan uji Chi Square terdapat hubungan Indeks Massa Tubuh (IMT) terhadap penyembuhan Luka Post Sectio Caesaria ( $P=0,000)$. (Yuniarti, Y, 202I) $\mathrm{Hal}$ ini sejalan juga dengan penelitian Nina Zuhana yang mengatakan bahwa status gizi berpengaruh dengan penyembuhan luka perineum ibu nifas. Kurangnya status gizi dapat mengakibatkan berkurangnya kekuatan luka, meningkat dehisensi luka, meningkatnya kerentanan terhadap infeksi dan parut dengan kualitas yang buruk (Zuhana et al., 2017). Sesuai dengan hasil penelitian Rati Permatasari (2017) di Puskesmas Gamping II Sleman menyatakan bahwa asupan gizi yang baik sangat penting untuk mempercepat proses pemulihan luka perineum dan penting untuk aktivitas, metabolisme dan cadangan dalam tubuh (Permatasari Rati, 2017). Dalam Penelitian Andi Ernawati,dkk juga mengatakan bahwa status gizi sangat berpengaruh terhadap lama penyembuhan luka perineum. Ibu nifas yang memiliki gizi kurang baik, lama penyembuhan luka perineumnya lebih dari 7 hari (Manuntungi et al., 2019). Dalam penelitian Lucya Lede hasil penelitiannya menunjukan bahwa terdapat hubungan yang signifikan antara status gizi dan lama penyembuhan luka perineum. Gizi merupakan salah satu faktor yang berhubungan dengan penyembuhan luka perineum dikarenakan status gizi ibu sangat berpengaruh terhadap pemulihan kondisi fisik ibu (Lede, 2019). Dalam penelitian Afrahrul Siregar tahun 202I di klinik $\mathrm{Hj}$. Dermawati Medan juga sejalan dengan penelitian sebelumnya bahwa status gizi mempengaruhi penyembuhan luka penerium (Siregar, 202I).

Hubungan Kadar Hemoglobin dengan
Penyembuhan Luka Perineum

Hasil analisis uji chi square diperoleh $\rho$ value 0,000 lebih kecil dari nilai $\alpha(0,05)$ yang berarti terdapat hubungan antara kadar hemoglobin dengan penyembuhan luka perineum.

Hasil penelitian ini sejalan dengan penelitian Tarsikah (2018) bahwa kadar hemoglobin mempengaruhi waktu penyembuhan luka perineum ibu nifas. Ibu nifas dengan kadar hemoglobin kategori anemia memilik resiko penyembuhan luka perineum lebih lama 4,7 kali di bandingkan ibu nifas dengan kadar hemoglobin kategori normal. Kesembuhan luka sangat di pengaruhi oleh suplai oksigen dan nutrisi ke dalam jaringan. Kadar hemoglobin yang normal akan mempersingkat waktu penyembuhan luka perineum karena kadar oksigenasi dalam darah meningkat sehingga proses penyembuhan luka maksimal (Tarsikah et al., 2018). Dalam penelitian Hema Malini, hasil penelitiannya mengatakan bahwa terdapat hubungan antara anemia dengan lama penyembuhan luka perineum. Kadar $\mathrm{Hb}$ yang kurang dari I I gr/dl memperlambat proses penyembuhan luka mengingat perbaikan sel membutuhkan kadar protein yang cukup. Karena itu, orang yang mengalami kekurangan kadar hemoglobin dalam darah akan mengalami proses penyembuhan luka yang lama (Malini, 2019).

\section{KESIMPULAN}

Terdapat hubungan yang signifikan antara pendidikan, status gizi dan kadar hb dengan penyembuhan luka perineum pada ibu nifas hari ke - 7 di Praktik Mandiri Bidan (PMB) kota Palangka Raya.

\section{UCAPAN TERIMA KASIH}

Terima kasih disampaikan kepada pengelola Jurnal Universitas Muhammadiyah Palangka Raya yang 
berkenan mendukung publikasi penelitian ini. Kepada Bidan di PMB wilayah Kota Palangka Raya serta ibu-ibu nifas yang berpartisipasi dalam penelitian ini.

\section{REFERENSI}

I. Rohmin, A., Octariani, B., \& Jania, M. (20/7). Faktor Risiko yang Mempengaruhi Lama Penyembuhan Luka Perineum pada lbu Post Partum. Jurnal Kesehatan, 8(3), 449. https://doi.org//0.26630/jk.v8i3.660

2. Dinas Kesehatan Provinsi Kalimantan Tengah. (2019). Profil Kesehatan Provinsi Kalimantan Tengah Tahun 2019. Dinkes Provinsi Kalteng

3. Yuniarti, Y. (20/8). Efektivitas Salep Jintan Hitam (Nigella Sativa) pada Proses Penyembuhan Luka Perineum Rupture Ibu Nifas. Jurnal Kesehatan Manarang, 4(2), 64 - 68. doi:10.33490/jkm.v4i2.76.

4. Pujiastuti, W., \& Hapsari, D. K. (20/7). Kadar Hemoglobin Rendah Menghambat Penyembuhan Luka Perineum di Wilayah Kabupaten Magelang. Poltekkes Kemenkes Semarang.

5. Notoatmodjo, S. (20I4). Ilmu Perilaku Kesehatan. Rineka Cipta.

6. Utami, N. H. (2017). Hubungan perawatan perineum dengan kesembuhan luka perineum pada ibu nifas di klinik bersalin widuri sleman.

7. Intiyaswati, I. (20I7). Faktor - Faktor Yang Mempengaruhi Penyembuhan Luka Episiotomi Pada Ibu Post Partum Di Pmb Istiqomah Surabaya. Jurnal Kebidanan, 9(I), 17-25. https://doi.org//0.47560/keb.v9il.237

8. Susilawati, S., Patimah, M., \& Imaniar, M. S. (2020). Determinan Lama Penyembuhan Luka Perineum pada Ibu Nifas Determinants of Perineal Wound Healing Period in Postpartum Mothers. 7(3), I32-136.

9. Zuhana, N., Prafitri, L. D., \& Ersila, W. (2017). Indeks Masa Tubuh terhadap Penyembuhan Luka Perineum Ibu Nifas. Jurnal Ilmiah Kesehatan (IIK), $X(2)$.

10. Permatasari Rati. (2019). Hubungan Tingkat Pengetahuan Dan Status Gizi Ibu Nifas Terhadap
Proses Penyembuhan Luka Perineum Di Puskesmas Gamping II Sleman.

II. Manuntungi, A. E., Irmayanti, \& Ratna. (20/9). Faktor-Faktor yang Mempengaruhi Lamanya Penyembuhan Luka Perineum pada Ibu Nifas di Ruang Perawatan Rumah Sakit Mitra Manakarra Mamuju. Nursing Inside Community, I.

12. Lede, L. (2019). Faktor-Faktor yang Berhubungan dengan Penyembuhan Luka Perineum di Wilayah Kerja Puskesmas Umbulharjo I Yogyakarta. Naskah Publikasi.

13. Siregar, A. P. (202I). Faktor Yang Berhubungan Dengan Penyembuhan Luka Jahitan Perineum Pada Ibu Post Partum di Klinik Hj. Dermawati Medan. 03(03), 259-268.

14. Tarsikah, T., Amin, I., \& Saptarini, S. (20/8). Waktu Penyembuhan Luka Perineum Ibu Nifas Berdasarkan Kadar Hemoglobin. MIKIA: Mimbar Ilmiah Kesehatan Ibu Dan Anak (Maternal and Neonatal Health Journal), 2(2). https://doi.org//0.36696/mikia.v2i2.43

15. Malini, H. (2019). Hubungan Anemia pada Ibu Nifas dengan Waktu Penyembuhan Luka Perineum di Puskesma Mlati II. Naskah Publikasi.

16. Kementerian Kesehatan, R. (2018). Profil Kesehatan Indonesia Tahun 2018. Kementerian Kesehatan RI.

17. Saiffuddin. (20/4). Ilmu Kebidanan Jakarta. PT. Bina Pustaka Sarwono Prawirohardjo.

18. Yuniarti, Y. (202I). Faktor-Faktor Yang Mempengaruhi Penyembuhan Luka Post Sectio Caesarea Di Rsud Dr. Doris Sylvanus Palangkaraya. Media Informasi, I6(I), 48-53. doi:https://doi.org/10.37160/bmi.v16il.413 